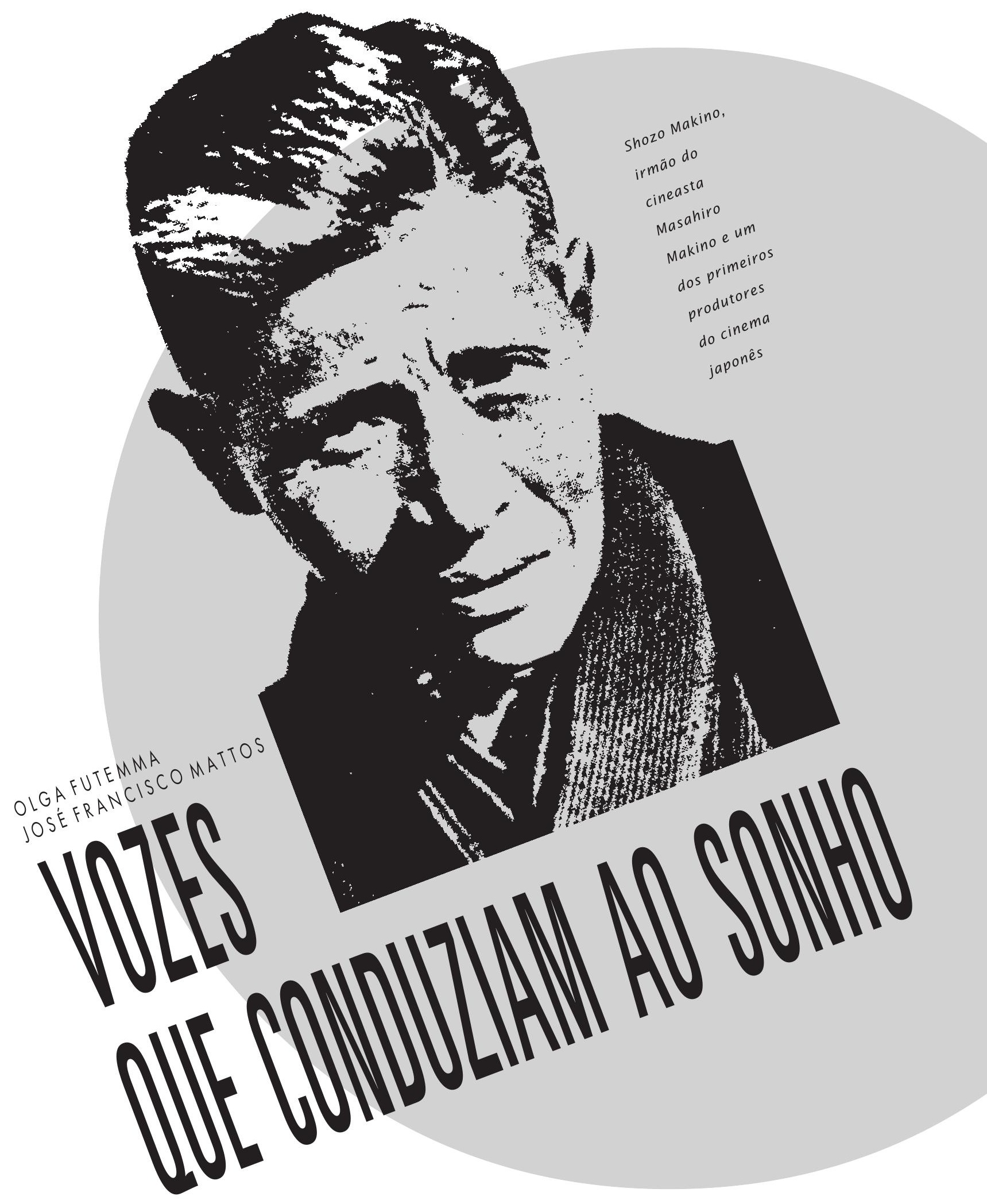




\title{
O katsuben
}

\author{
e a história
}

do cinema

japonês no

seu tempo

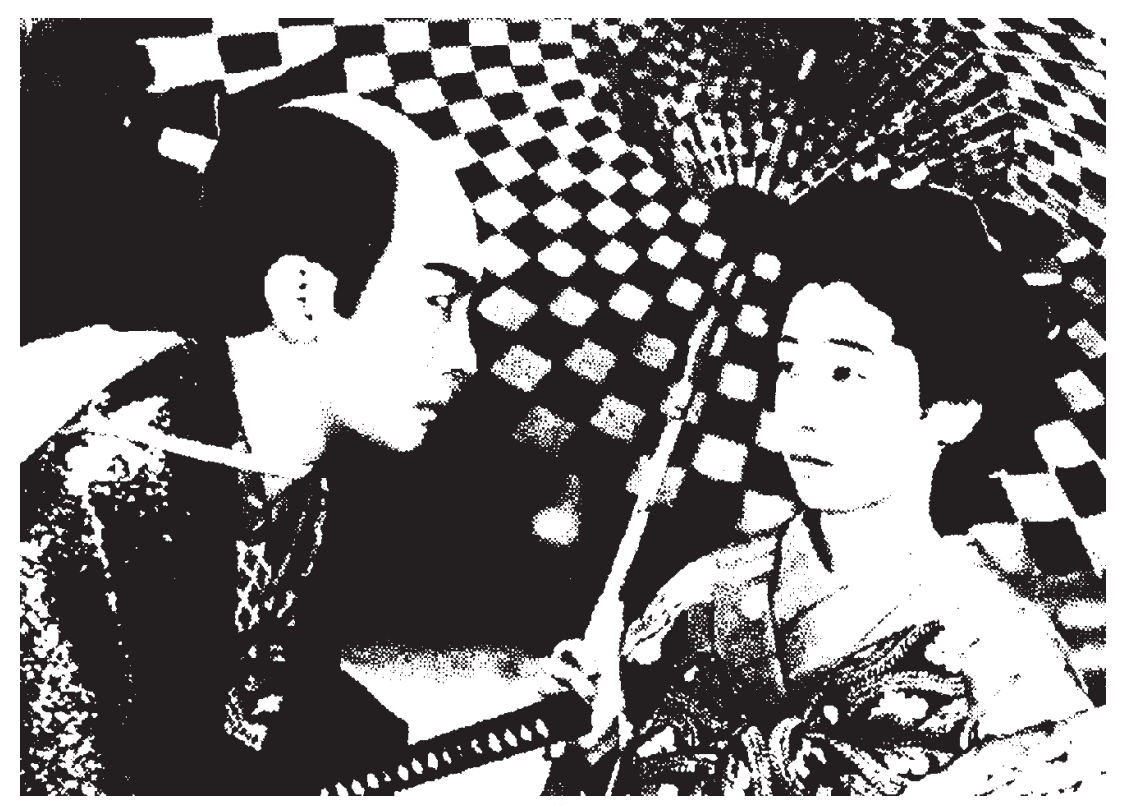

47 Ronins, 1932, dirigido por Teinosuke Kinugasa

$\mathbf{J}$

apão, início dos anos 30. Sala de cinema. O katsuben - termo que engloba USUdo sashin, "fotografias móveis", e BENshi, "locutor ou comentador" - fazia sua entrada no palco como o verdadeiro dono do espetáculo. Colocava à sua frente uma tabuleta com o seu nome e o título do filme a ser exibido e se preparava para a liturgia da palavra, para tirar do cinema feito até essa época aquilo que passou a ser sua definição, o silêncio. Trajando um quimono formal para a apresentação de obras japonesas ou fraque e calças risca-de-giz para filmes estrangeiros, este artista - ao contrário de dubladores de filmes mudos no Ocidente que se escondiam atrás da tela, na tentativa de atuarem de modo transparente - postava-se ao lado da cena, completamente visível pelo público e dava início ao programa. Antes, porém, da sessão de cinema, o início do cinema no país.

Depois de séculos fechado ao mundo exterior, o Japão da Restauração Meiji (18681912) emerge com avidez pelo conhecimento e tecnologia do mundo ocidental. A intro- dução de técnicas estrangeiras no Japão acontecia de modo harmonioso, desde que preservadas as singularidades de sua cultura. Não há uma homogeneização de elementos. É nesse quadro que aparece o cinema, cuja certidão de nascimento teve por testemunha uma princesa. Isto é o que se depreende da pequena nota social publicada no jornal de Kobe, Yushin Nippon, em 21 de novembro de 1896, sob o título "Da Corte e dos Príncipes”: “.... princesa Arisugawa, que está morando em sua residência em Maiko, viu um 'filme', a recente invenção de Edison, em máquina de propriedade de Shinji Takahashi...”. A máquina era um kinetoscope comprado por Takahashi, um comerciante de fuzis, e o filme não foi o primeiro a chegar ao país. As primeiras películas dos irmãos Lumière já estavam no Japão há alguns meses, mas na ausência de um projetor só podiam ser vistas ao ser desenroladas com as mãos, à maneira dos kakemonos, antigas pinturas em rolo. Não tiveram nenhuma repercussão.

A apresentação do vitascope, o projetor
OLGA FUTEMMA

e realizadora de curtas-metragens e videos e pesquisadora da Cinemateca Brasileira.

\section{JOSÉ FRANCISCO}

MATTOS

pesquisador da

Cinemateca

Brasileira. 
de Edison, aconteceu em Osaka em novembro desse mesmo 1896. Quatro meses depois, dois cinematógrafos Lumière aportavam em companhia de um operador, também francês, na mesma cidade. Por essa época, Shoten Yoshizawa adquiriu um aparelho dos irmãos franceses e, não se limitando apenas à exibição da novidade como os outros importadores, mais tarde produziu o primeiro cinejornal japonês. A primeira câmera, uma Gaumont que utilizava filmes de 20 metros, foi importada ainda em 1897. O operador Shiro Asano registrou cenas de ruas movimentadas de Tóquio. Sua filmagem seguinte foi de uma dança de gueixas, em 1899. O longo tempo entre seus trabalhos pode ser explicado pela enxurrada de filmes estrangeiros que inundavam as salas onde aconteciam as exibições.

Kanzo Shirai e Tsunekichi Shibata também registraram danças de gueixas em 1899. Desses dois pioneiros, apenas o último continuou na profissão e rodou no mesmo ano Inazuma Goto (Ladrão Relâmpago), em setembro, e Momijigari, em novembro, que foram, ou não, considerados filmes de ficção se assim quiseram os katsuben que os apresentaram. Inazuma Goto, baseado em fato da época, mostra, numa cena de dois minutos, a captura de um ladrão por dois policiais. Momijigarié uma cena de peça kabuki, interpretada por Danjuro Ichikawa IX e Kikuguro Onoe V, em que um homem conquista uma ogra que se faz passar por uma princesa. Nio no Ukisu, filmado por Tsuneji Tsuchiya em julho de 1900, mostra um cortejo de gueixas vindo em direção à câmera, colocada quase ao nível do chão, observado por dois homens, um deles interpretado por Ganjiro Nakamura, o protagonista de Fim de Verão, de Ozu. Era um trecho de peça no estilo shin-kabuki, uma renovação do gênero teatral.

Devido ao sucesso dos documentários de guerraimportados, Yoshizawa enviou Shibata e um outro cinegrafista à China para cobrir o conflito dos Boxers, em 1900. Um dos resultados da empreitada, Hokushinjihen Katsudo Daishashin (Grande Filme da Rebelião Boxer), que estreou em outubro daquele ano, é considerado o primeiro cinejornal japonês, já que as cenas de rua, danças das gueixas ou até uma competição de sumô filmada por
Tsuchiya naquele abril não foram feitas com o propósito de mostrar atualidades.

Em 1902, a companhia de Yoshizawa filmou uma corrida de bicicletas e um ano mais tarde, além de vários jornais rodados em diferentes cidades, registrou três funerais, seguindo uma moda do cinema ocidental. $\mathrm{O}$ primeiro, de um monge. O segundo, do ator Kikugoro Onoe V, de Momijigari. O último documentou o enterro do príncipe Komatsunomiya, na estréia cinematográfica da família. A deferência com os imperadores tem início aí. Em outro documentário da companhia, este sobre a guerra russo-japonesa, produzido em 1905, quando a carruagem imperial passa e os soldados abaixam a cabeça em sinal de respeito, a câmera também se abaixa e focaliza um crisântemo gravado na porta do veículo. O respeito, inclusive, era extensivo aos projecionistas que, operando manualmente os equipamentos, estavam orientados a rodar mais devagar a manivela quando algum dos membros da família imperial estivesse em cena.

Essa guerra iniciada em 1904 foi assunto para pelo menos doze cinegrafistas, sendo que dois deles acabaram como prisioneiros de guerra. Nem com esse contingente a produção atendeu à demanda do público. Começaram então a aparecer falsos documentários da guerra feitos por estrangeiros. Com o tempo, os próprios japoneses passaram a produzir essas ilusões de realidade, vestindo extras com uniformes militares e mostrando muita fumaça para dar a impressão de batalha. $\mathrm{O}$ fato é que $80 \%$ da produção lançada entre 1904 e 1905 se referiam a documentários sobre a guerra, verdadeiros ou falsos. Uma das consequiências dessa atividade foi o surgimento dos primeiros laboratórios cinematográficos. As fitas com outros assuntos, que incluíam filmes turísticos ou de dança, eram exibidas como complemento daqueles.

Mesmo no mercado dominado por produções estrangeiras, principalmente as da França servidas à moda japonesa - os filmes americanos só seriam predominantes com a eclosão da Primeira Guerra Mundial -, esses anos iniciais viram surgir as interessantes atividades de Toyojiro Takamatsu. Militante socialista e rakugoka (narrador de rakugo, 
história cômica) de profissão, Takamatsu, munido de gramofone, projetor e filmes, rodava o país como ambulante. Suas apresentações envolviam a exibição, as histórias de sua própria autoria e o discurso socialista. É o único caso de katsuben politicamente engajado de que se tem notícia. Em 1903 passa a produzir seus filmes, baseados em seus contos, nos quais a doutrinação encontrava um pano de fundo mais condizente.

Se durante a guerra russo-japonesa muitos operadores filmaram, com o fim do conflito, a atividade cinematográfica foi monopolizada pelas companhias Yoshizawa e pela Yokota, que insistiram no documentário. Com o sucesso obtido com o relançamento de Momijigari, em 1907, elas voltaram suas lentes para as encenações teatrais. Quando se fala de fragmento de filme japonês primitivo, isto não quer dizer obrigatoriamente o trecho sobrevivente de uma obra desaparecida. Um exemplo: se o programa era Chushingura Godanme (1908), da Yoshizawa, em vez do drama dos 47 samurais vingadores de seu amo que havia sido vítima da perfídia de um nobre corrupto, o que o público assistia era a uma cena de troca de trajes de três atores, com a câmera estática a dez metros do palco. A história ficava por conta do katsuben. (Como Chushingura Godanme tinha três rolos de comprimento, durante a filmagem, quando da troca de bobinas na máquina, os intérpretes paravam exatamente como estavam e esperavam. Na época, o comum era rodar apenas um rolo de aproximadamente 50 metros, uns seis minutos de projeção.) Com a exigüidade de capital, uma outra singularidade japonesa era a velocidade de oito fotogramas por segundo. O padrão mundial no período eram 16 quadros. Atualmente os filmes são sensibilizados e projetados em 24.

Apesar da indigência econômica do meio cinematográfico, o país estava começando a produzir um número assombroso de películas. Em 1908, aproximadamente 50 títulos, e dois anos mais tarde, acima de 300 , já com um estúdio da Pathé lá instalado. Com o aumento da produção, foi maior a procura por intérpretes. As figuras mais famosas do kabuki não se dignavam a atuar em entretenimento tão popular como o cinema. O recurso dos estúdios foi perscrutar elementos menos nobres. É nessa época que o diretor Shozo Makino descobre o ator itinerante de kabuki Matsunosuke Onoe, que se tornou o primeiro astro do cinema japonês e fez, até a sua morte, em 1926, aproximadamente mil filmes de época. Com o sucesso do ator, os atores do teatro tradicional passaram a se aventurar nas telas. Instalado em Quioto, Shozo Makino primeiro trabalhou para Shokai Yokota, foi para a Nikkatsu e alguns anos depois abriu sua própria produtora. Entre 1909 e 1911 dirigiu 170 filmes com Matsunosuke.

A introdução de novos gêneros também foi motivada pelo aumento da produção. O filme de ambientação contemporânea, de influência ocidental, surge nesse momento e uma das primeiras expressões é o melodrama One ga Tsumi, da Yokota, baseado em um best-seller que serviu ainda de base para muitos outros filmes, como sempre foi comum no cinema japonês. Baseado é uma força de expressão, já que apenas duas cenas à beira-mar foram filmadas. Inspirado em cópias francesas dos filmes de perseguição americanos, Imori no Kuroyaki, também da Yokota, mostra um jovem apaixonado sendo caçado por uma velha mendiga depois de ter errado o alvo ao lançar um pó mágico na amada. Na exibição das cenas de perseguição, auto-explicativas, a voz do katsuben arrumava um jeito de fazer a sonoplastia, emitindo uma série de ruídos onomatopaicos. Outra experiência da época é o rensageki (drama encadeado) em que palco e tela tornavam-se um todo. Para compreender o espetáculo a platéia precisava acompanhar a ação dos atores no palco, assim como na tela, quando as luzes da sala se apagavam e a projeção do filme continuava a história, como se ele estivesse ocorrendo, naquele momento, em outro local. Foi comum a exibição posterior desses filmes apenas com a participação dos katsuben.

Esta inovação, entre outras tentativas do período, não teve vida longa. No centro da questão estava talvez a resistência do Japão em assumir um modo ocidental de fazer cinema ou da platéia em entender esse modo. Os filmes começaram a intercalar mais cenas por rolo que a usual média de apenas seis e au- 
mentaram suas metragens. Da junção dos estúdios Yoshizawa, Yokota e Pathé com a cadeia de cinemas Fukuhodo foi criada a empresa Nikkatsu, em 1912, monopolizando a produção e a exibição. O fato de o truste ter estúdios em Tóquio e em Quioto assinala geograficamente a divisão de estilos característicos da produção. $\mathrm{Na}$ antiga capital eram produzidos os filmes de época. Em Tóquio, os modernos. Mesmo com a evolução da linguagem cinematográfica, mantiveram-se os katsuben e os onnagata (atores especializados em personagens femininos), uma tradição do teatro kabuki, reproduzida até no cinema de ambientação moderna. As mulheres só pisariam em um estúdio em 1919. Cinco anos antes, com o início da guerra européia, os Estados Unidos passam a dominar na área dos filmes estrangeiros.

Os filmes de Quioto até o início dos anos 20, baseados no kabuki e no popular kodan (narrativa de façanhas históricas, originalmente oral), retratavam legendários samurais e heróis plebeus, que defendiam virtudes do sistema feudal, tais como honra e lealdade, com clara distinção entre o bem e o mal. Os heróis populares, como ladrões ou yakuza escrupulosos que defendiam oprimidos, nunca ficavam impunes. O consciencioso Nezumi Kozo Jirokichi, personagem de várias películas, que só assaltava ricas mansões ou samurais malvados, sempre era capturado pelos guardas do shogun. Um episódio exemplar é o narrado por Chushingura, em uma de suas muitas versões. Os 47 samurais, depois de vingar a morte de seu amo, obtêm permissão para fazer o haraquiri para remediar seu leal mas ilegal ato.

A produção de Tóquio quer ser moderna, realista. Fazer cinema de pronta entrega, com intertítulos, sem a intermediação entre platéia e tela. Através do filtro do teatro shimpa (movimento renovador com encenação de dramas contemporâneos, introdutor no país do palco italiano), os autores estrangeiros são transpostos para as telas. Com o público, passa a existir um problema: como entender o enredo, se as histórias já nem eram aquelas velhas conhecidas? Ainda não é dessa vez que o katsuben foi abolido. O estilo de filme moderno que predomina é o melodrama. Dois dos mais populares filmes da época são baseados em Tolstói: Katsusha (1914), adaptação de Ressurreição, e O Cadáver Vivo (1917), em que Sacha era vivida pelo então astro número 1 da Nikkatsu, o onnagata e futuro cineasta de Jigokumon (Portal do Inferno), Teinosuke Kinugasa.

Mais ou menos na época em que as mulheres passam a atuar como atrizes, por volta de 1920, os dois irmãos gêmeos Othani fundam a Shochiku em Tóquio. A criação dessa companhia enfim dá uma face de indústria para a produção cinematográfica japonesa. Com a compra de bons equipamentos, contratação da melhor mão-de-obra disponível, política de compra de pequenos estúdios e construção de salas por todo o país, a empresa se propõe a modernizar o ambiente. Rojo no Reikon (Almas na Estrada, 1921), de Minoru Murata, foi o primeiro filme, no qual duas histórias, uma delas de Máximo Górki, se entrelaçam. Parecia um bom começo que o terremoto de 1923 levou ao chão. Quioto se transforma em capital do cinema e a Nikkatsu, na única companhia a possuir um estúdio.

Tentando amortizar os prejuízos causados pela catástrofe, as duas produtoras, com a Nikkatsu alugando suas instalações para a concorrente, passam a filmar maciçamente, mas com qualidade inversamente proporcional à quantidade de obras. Só em 1924, são lançados 875 títulos. Se de um lado a mediocridade da produção alargou o caminho para a exibição de filmes americanos, também fez com que Shozo Makino criasse uma terceira companhia e assumisse os ideais artísticos com os quais a Shochiku originalmente havia tentado se comprometer. E os filmes de samurai começam a questionar os antigos valores. O protagonista que se rebela contra a autoridade começa a ser glorificado. É quando aparece o herói niilista de Buntaro Futagawa em Orochi (O Samurai Serpente, 1925), interpretado pelo ator Tsumasaburo Bando. O filme relata o trágico declínio de um jovem samurai rejeitado pela mulher que ele ama e injustamente expulso de seu clã. Na vida marginal, acaba preso pelo assassinato de um homem tido como respeitável. Ao ser conduzido pelas autoridades, o povo se aglomera para ver o 
fora-da-lei, que até mesmo ele acredita ser.

No ano seguinte, o agora cineasta Teinosuke Kinugasa faz Kurutta Ichppeiji, cuja ação se passa quase que exclusivamente em um manicômio, onde uma mulher que tentou se afogar com seu bebê está internada. Foi o único filme japonês surrealista da década e seu diretor, ao assisti-lo acompanhado pela narração de Musei Tokugawa, ficou encantado com as explicações do katsuben, que combinava com o espírito avant-garde de sua obra. A soma das discussões teóricas do cinema como arte, que integravam o cardápio da intelectualidade, com os questionamentos das mensagens veiculadas dava o sinal inequívoco de que o cinema chegara à adolescência. Mais alguns anos e a maioridade era alcançada. O final dos anos 20 marca a consolidação da arte de Kinugasa, Kenji Mizoguchi, Heinosuke Gosho, Yasujiro Ozu, Tomu Uchida e a estréia de Mikio Naruse e Tomotaka Tasaka. Com esse time de comandantes e contando ainda com Kinuyo Tanaka, Chiezo Kataoka, Kazuo Hasegawa, Denjiro Okoshi e Hideko Takamine, que eram parte da vitrine mais vistosa que o Japão mostrou para o mundo vinte anos depois, o cinema navegava apenas em leito muito mais que tranqüilo.

Até as inovações do filme dotado de pista para som para os cineastas eram só uma expansão técnica com o objetivo de melhor transmitir suas idéias. A primeira experiência aconteceu em 1927 e o sucesso de público veio quatro anos depois com o cheio de silêncios Madamu to Nyobo (A Vizinha do Lado), de Heinosuke Gosho. A produção de filmes sonoros se torna predominante no ano seguinte ao da criação da Toho, 1934. Em 1937, um quinto dos lançamentos ainda era silencioso. Aliás, o filme silencioso só deixou de ser produzido em 1941, por decreto militar. O governo proibiu o uso do nitrato, com o qual as películas eram feitas, a fim de reservá-lo para a fabricação de explosivos.

A comoção no meio cinematográfico com a chegada do som ao cinema atingiu também o Japão. Se em alguns aspectos, como adaptação de roteiros para as falas de personagens, adaptação de vozes aos atores que as emitiam, adaptação dos projetores e abolição dos músicos que acompanhavam as sessões, o rebuliço foi similar ao do resto do mundo, no que se refere aos katsuben a coisa foi bem outra.

Voltando à sala de cinema dos anos 30, à sessão que abandonamos no início deste texto, o katsuben, postado ao lado da tela, era tão importante que fazia do filme acessório de sua performance. Equipado com um botão na sua plataforma, que fazia soar uma campainha na cabine de projeção, ele instruía um projecionista quanto a alterações na velocidade de projeção (um toque longo, ralentar; dois, acelerar) e mesmo quanto a interrupções, e podia ignorar as brochuras de diálogos que acompanhavam uma fita para improvisar um outro enredo a partir das mesmas imagens. Todo esse domínio de tempo obedecia evidentemente a exigências dramáticas de sua narrativa em detrimento daquelas do próprio filme, mas também a questões mais práticas de freqüência de público - muito público, mais sessões, menos tempo - e a um certo critério de importância da película.

Pode-se dizer que, embora lidando com uma mídia inteiramente nova - o cinema -, a “invenção" do katsuben resgatava para a platéia as tradicionais experiências de ouvir histórias narradas ou cantadas em espetáculos de rua, no teatro kabuki e nas peças bunraku: o públicojaponês sempre conseguiu lidar com elementos de grande opacidade, como os condutores dos bonecos bunraku que, ainda que vestidos de negro e com capuzes, são completamente visíveis e não apenas não atrapalham a emoção no acompanhamento do enredo, como são importantes para a criação dessa emoção. A essa característica particular de retomar de maneira teatral a apresentação de um filme, podemos somar determinantes econômicos para a utilização desses narradores, desde a constatação de que o seu salário era muito menor do que o custo de uma legendagem, quanto a complementação necessária do tempo padrão de duração dos espetáculos, já que aluguéis de filmes eram relativamente caros.

O número de katsuben variava de acordo com a natureza da película. Documentários e filmes turísticos requisitavam apenas um narrador. Do mesmo modo que os filmes 
estrangeiros: além de traduzir os intertítulos originais, ele estabelecia pontes entre as cenas - função tanto mais necessária quanto maior a complexidade da linguagem cinematográfica utilizada-,identificava personagens, uma vez que, para o público japonês, os ocidentais se parecem demais uns com os outros, podendo daí ocorrer confusões no entendimento da história. Sobre essa função de reconhecimento de personagens, o professor Paulo Emílio Sales Gomes reconta, em seu artigo "Singularidade do Japão", o caso do katsuben Tenrei Izumi, especializado em filmes americanos: por não identificar bem as fisionomias, criou as personagens de Mari e de Kare (ele, em japonês), o marido de Mari. Em todos os filmes, as histórias eram sobre Mari e Kare, seus ascendentes e descendentes.

Para os filmes japoneses de ficção, uma equipe que continha de quatro a oito profissionais realizava em revezamento uma espécie de dublagem ao vivo, sem uma divisão de personagens como as dublagens atuais, e tecia comentários que sustentavam as longas cenas de planos únicos, linguagem de não-interferência, que procurava manter a experiência teatral. Freqüentemente os programas continham três filmes, com uma duração total de quatro horas. Essa longa duração para os padrões ocidentais evoca o padrão teatral tradicional de quatro a seis horas, e explica em parte o surgimento do grande número de katsuben. Às mulheres katsuben ficavam reservados os curtas e filmes românticos importados: num mundo dominado quase que absolutamente por homens, como o do showbusiness, é interessante constatar que, num registro de 1920, foram listados 750 homens e 90 mulheres katsuben trabalhando em Tóquio, proporção muito menor que a de 1927 em todo o país: dos 6.818 profissionais, apenas 180 eram mulheres.

Nesse período do cinema dito silencioso, inversamente aos esforços do Ocidente em criar uma linguagem independente, o cinema japonês se desenvolveu no sentido de respeitar a presença do katsuben no espetáculo cinematográfico. O fato de ele se encaixar naturalmente no sistema de exibição se deve a que grande parte dos filmes japoneses primitivos de ficção eram adaptações de histórias do kodan (tradição oral apresentada por apenas um narrador), da literatura impressa advinda do kodane, em menor grau, do kabuki e de peças de joruri (balada narrativa com acompanhamento de instrumentos musicais, a música do bunraku). Para o público, o cinema era uma extensão desses gêneros já conhecidos, que integravam sempre a presença de narradores, acrescida de enredos que se apoiavam em imagens em movimento.

Aliás, "apoio" é uma palavra que poderia ser substituída por "pretexto" à arte por vezes exclusivamente de improvisação, como nos relata Paulo Emílio no mesmo artigo, ao descrever o exemplo extremo do domínio da palavra sobre a imagem nessa época ironicamente conhecida como do cinema mudo: para a inauguração de uma nova sala, foi anunciado um longo espetáculo no qual seria contada a história do peixe vermelho. "O público compareceu, trazendo suas refeições. Durante dez horas, enquanto eram projetadas continuamente as mesmas imagens, o benshi contou sem interrupção histórias do peixe vermelho. $\mathrm{O}$ filme de que dispunham mostrava as evoluções de um peixinho num aquário e durava apenas alguns minutos."

A prova de que a categoria dos katsuben alcançou grande popularidade está documentada em livros e testemunhos da época. O público se dispunha a ver o mesmo filme, com narradores diferentes, para comparar performances; artistas viajavam pelas cidades principais, em tournées, acompanhados de filmes (e não o contrário), tendo toda a publicidade estruturada a partir de seus nomes; torneios eram organizados para julgamento de talentos, e gráficos de popularidade estabeleciam a margem de negociação entre o profissional e os donos das salas. É preciso ressaltar, entretanto, que não se tratava de uma profissão respeitada, à exceção talvez do curto período de glória - de 1927 a 1931-, quando os mais renomados passaram a ter salários iguais ou maiores que os de diretores e astros de cinema, porque mais amados que estes: ao longo de sua história, se comparados com os professores, por exemplo, mal pagos mas tratados com extrema deferência, constata-se que aos katsuben ficava reservado um lugar modesto na escala social. Ainda que amados, 
imitados e assediados por fãs, de um lado não carregavam a aura de uma arte tradicional, de outro habitavam o núcleo de uma atividade economicamente marginal.

$\mathrm{O}$ ingresso na profissão acontecia, digamos, informalmente, como nas atividades artesanais. Os candidatos, de um modo geral, não possuíam nenhuma experiência ou formação em interpretação. Algumas cadeias de sala de exibição promoviam cursos, mas o sistema de treinamento que se impôs foi o de mestre-discípulo. Terminada a etapa de orientação, observação e ensaios, o pupilo debutava em cinejornais, passava a curtasmetragens e finalmente, caso consolidasse seu nome, especializava-se no longa-metragem. $\mathrm{Na}$ ausência de uma tradição estabelecida especificamente para a sua arte, os estilos de narração eram ecléticos, adaptados das tradicionais artes de contar histórias, formas de interpretação com um só narrador, às quais eram permitidos recursos estritos, como gestos, expressões e no máximo um leque como acessório, e que requeriam um longo aprendizado até ser alcançado o estatuto de mestre. É bem verdade que a história dá conta de vários dos mestres dessas artes que abandonaram seus privilegiados postos para assumir um lugar na galeria dos katsuben, espaço que abrigava também artistas de rua e anunciadores de espetáculos. Enquanto nas artes tradicionais seus mestres aperfeiçoavam um dado repertório por anos a fio, o cinema, desde então, carregava o saudável convite ao aventureirismo (bastava, por vezes, o candidato possuir o “dom”), devido talvez à sua própria efemeridade: representava-se um filme sem grandes ensaios, improvisava-se... e na semana seguinte seria outro filme.

Não há dúvida, portanto, de que a inserção das diversas artes de contar histórias no panorama do espetáculo japonês obedecia a uma hierarquia, e nela a arte dos nossos heróis, ainda que entusiasmasse a platéia, ainda que inegavelmente tornasse o cinema uma encantadora performance multimídia, não poderia competir com tradições tão solidamente instaladas. E parece que não investiram esforços nesse sentido. Em vez disso, buscaram alargar seus espaços, através de parcerias novas, na perspectiva da expressão autônoma (interpretação “sem” acompanhamento de filmes). No auge da popularidade dos katsuben, quando os fãs chegavam a declamar, de memória, trechos de suas falas, discos com resumos de apresentações tiveram boa vendagem; a partir de 1925 até meados da década de 30, interpretações eram transmitidas por rádio, meio como versões dialogadas de filmes silenciosos; mesmo após o advento do cinema sonoro, os ouvintes podiam acompanhar ao vivo as vozes de seus narradores preferidos sobrepostas ao som original da película estrangeira, este sempre em volume baixo, fornecendo "a base".

$\mathrm{Na}$ outra ponta desse feixe de variantes e mediações, a autonomia quase absoluta, a eliminação do próprio filme do espetáculo ainda que preservada a sua origem. Como nos conta J. L. Anderson no definitivo ensaio "Spoken Silents in the Japanese Cinema", no livro Reframing Japanese Cinema, do qual emprestamos várias informações para este texto, "algumas vezes as interpretações de filmes tinham tanto sucesso que os katsuben mantinham-nas vivas em seus repertórios pessoais bastante tempo após os filmes estarem fora de cartaz. Musei Tokugawa interpretou seu $O$ Gabinete do Doutor Caligari por meio século - em geral sem o filme".

O mesmo Anderson distingue três funções básicas desempenhadas pelo katsuben. A primeira, essencial, referia-se evidentemente à arte vocal, através da qual ele realçava o filme sem voz, estimulava outros sentidos para que se articulassem com a visão, fazia do filme "uma experiência sensorial mais completa". A leitura de intertítulos fazia parte dessa função narrativa, mas uma narrativa livre, que incluía tradução, quando era o caso, comentário e criação de diálogos -, numa ampliação extraordinária do sentido de dublagem, às vezes até mesmo na negação desse conceito, à medida que, por contar com um repertório limitado de vozes, não se fazia a correspondência voz-personagem. Nessa função também habitava a possibilidade da subversão dos desígnios do filme, da não-submissão à fala impressa, da criação de tensões, através de ironias ou comentários oblíquos, entre o que o público via na tela e o que ouvia do katsuben. Mais: conscientemente ou não, ao 
transferir para o cinema a tradição dos contadores de história em que o que se conta está, claro, no passado, eliminando a transparência que o filme sempre procurou alcançar - a ilusão de que o que ocorre na tela é o aqui e o agora -, esse artista capturava para si a incumbência do espetáculo presente.

A segunda função de explicador podia dar a medida do talento de um katsuben. Por ser área de intervenção livre, de repertório externo trazido por ele para dentro do filme, podia significar tanto a intrusão em um trabalho cinematográfico de boa qualidade - uma tagarelice apenas -, quanto a valorização de um filme que, de outro modo, seria não mais que comum, ou mesmo a salvação de um mau filme. Se nos primeiros tempos houvera real necessidade dessa função, principalmente para comentar costumes desconhecidos em filmes estrangeiros, depois ela se manteve para dar suporte ao estilo da fita e para pôr à prova o equilíbrio narrativo de cada entertainer.

É esta sintonia que se encontrava no núcleo da sua terceira função, o de representante da sua platéia, o de espectador ideal. Quanto mais ele soubesse reagir ao filme como seu público esperava que ele o fizesse, maior a sua legitimidade em liderá-lo. Para Anderson, "como outros performers, os katsuben objetivavam que suas atuações transcendessem o significado das palavras. O processo era o que entretinha. É o que fazia do evento, arte". Sessão após sessão, eles podiam aferir os resultados, visto que as manifestações da platéia eram extremamente informais: as passagens virtuosas eram saudadas com gritos de aprovação, enquanto as medíocres eram recusadas com apupos, também em voz alta ("Trabalhe direito!", "O saquê vai te matar!").

Com os katsuben, cada apresentação era uma experiência única. O grande desafio era o de eliminar a distância entre sua atuação e o público, e finalmente conduzi-lo ao sonho. De transformar a experiência do filme em muito mais do que olhar fotografias em movimento. Porém, o filme sonoro se impôs também no Japão, seguindo uma tendência mundial e apesar de toda movimentação em torno desses artistas. De início foi a chegada dos filmes estrangeiros totalmente sonorizados. A primeira providência tomada, a de simples- mente abaixar todo o volume da pista de som e continuar com seu trabalho, resultou em alguns procedimentos curiosos-O Anjo Azul, de Von Sternberg, exibido com katsuben, teve as canções de Marlene Dietrich cantadas ao vivo em língua japonesa. Em seguida, até por levar em conta o desejo do público, sobrepôsse o som original à atuação dos narradores, provocando a situação, descrita por um crítico, em que "o filme fala e o katsuben berra". A segunda ameaça foi caracterizada pela decisão dos exibidores de legendar os filmes estrangeiros.

A derrota veio quando a produção japonesa, responsável por 2/3 do mercado, decidiu-se - ainda que vagarosamente - pelo filme sonoro. Acuados pelo perigo do desemprego, os katsuben entraram em greve. Em 1932, ocorreram 203 movimentos contra os filmes sonoros. Nem mesmo o sindicato que haviam conseguido organizar teve forças para deter a devastação provocada por esse avanço tecnológico do cinema.

Akira Kurosawa dedica grande parte de sua autobiografia ao irmão mais velho, um katsuben. Heigo fazia parte, sob a liderança de Musei Tokugawa, aquele "cuja voz majestosa conduzia ao sonho", de um grupo que realizava "narrações de alta qualidade para os bons filmes estrangeiros" e tornara-se narrador-chefe de uma sala. Através deste irmão e dos ingressos que recebia para os espetáculos e dos amigos também contadores-de-histórias, Kurosawa pôde ver os filmes que quis, saboreou a arte desses profissionais, aprendeu com os velhos que tinham empregos como o de cuidar dos sapatos de pessoas que iam ao cinema. Como todos, sentava-se sobre os tatami e "gastava o dia inteiro assistindo a filmes e ouvindo histórias”. Ele conta:

"Com o advento do cinema falado [...] encerrava-se a era dos narradores. A vida de meu irmão foi seriamente atingida. A princípio, tudo parecia estar bem, porque ele era o narrador-chefe de um cinema importante, o Taikatsukan, em Asakusa, onde tinha seu próprio séquito [...] As salas exibidoras decretaram, como política universal, que não havia razão de manter narradores. Profissionais foram despedi- 
dos em massa e, ao tomar conhecimento disso, a categoria entrou em greve, meu irmão, como líder dos trabalhadores grevistas, enfrentava dificuldades [...] Um dia, soubemos que meu irmão tentara o suicídio. Creio que essa atitude foi motivada por seu fracasso como líder grevista. Ele parecia aceitar o fato de os narradores não mais serem requisitados, com o desenvolvimento da tecnologia sonora. Sabia que lutava uma batalha perdida e o fato de ter sido levado a liderar o movimento causara-lhe uma dor indescritível...".

Embora salvo dessa tentativa, Heigo Kurosawa suicidou-se alguns meses depois, cumprindo a sua profecia, já anunciada anteriormente à sua família, de que morreria antes de completar trinta anos. Conjecturar sobre a responsabilidade que a situação profissional sua e dos amigos teve para a sua decisão é algo que nem mesmo o irmão cineasta ousa fazer. O certo é que, em meio aos festejos sonoros, este foi um momentomelancólico, mesmo para o cinema, mesmo para aqueles que saudaram o progresso e defenderam ardorosamente o cinema falado. Ao se excluir a figura do katsuben, decretou-se, por muito tempo, o fim da comunicação enamorada pelo cinema. Talvez, se "a irmã gêmea da tecnologia", a nostalgia, tivesse se manifestado naquele momento, seguramente haveria lugar para o katsuben no cenário artístico que se seguiu - pudesse o mundo ter feito algum esforço no sentido de harmonizar o que já era tradição e a novidade do momento. Como, aliás, fizeram os próprios katsuben ao longo de sua existência: harmoni- zar, adaptar. Abraçar a singularidade de sua cultura, exposta à ventania de imagens que nasciam no mundo.

Além do êmulo japonês do americano Cantando na Chuva, a comédia Katsuben Monogatari, 1957, dirigida por Seiichi Fukuda, o trabalho sério de resgate dessa arte no Japão esteve a cargo de Shunsui Matsuda, um artista da segunda geração, conhecido como "o último dos katsuben". Nascido em Tóquio, em 1925, estreou na profissão aos cinco anos de idade. Depois da Segunda Guerra Mundial, retomou sua atividade e criou a Musei Eiga Kanshokai, destinada a preservar a arte dos katsuben e os 1.000 filmes japoneses primitivos que coletou. Em 1952 , fundou a Matsuda Eigasha que, além de filmes, produz novos katsuben, através de uma escola. Um ano antes de sua morte, em 1987, dirigiu com o crítico Tadao Sato o documentário de longa-metragem Bantsuma: Bando Tsumasaburo no Shogai, sobre "o maior espadachim do cinema". Entre trechos de outros filmes estrelados pelo ator, há um de $O$ Samurai Serpente, no qual podemos ouvir Shunsui Matsuda como narrador.

Foi justamente $O$ Samurai Serpente um dos programas da mostra "Benshi: a Magia do Cinema Mudo Japonês", promovida pela Fundação Japão. Para interpretar este e os outros dois filmes Oatsurae Jirokichi Goshi (Jirokichi, o Rato, 1931) e Taki no Shiraito (A Feiticeira das Águas, 1933), exibidos no MIS em dezembro de 1995, a mais importante katsuben do Japão, ex-discípula de Matsuda, Midori Sawato deu uma demonstração desta arte que julgávamos irremediavelmente perdida.

\section{BIBLIOGRAFIA}

GOMES, Paulo Emílio Sales. Crítica de Cinema no Suplemento Literário - Volume 1. Rio de Janeiro, Paz e Terra, 1981.

KOJIMA, Setsuko \& CRANE, Gene A. A Dictionary of Japanese Culture. Tóquio,The Japan Times, 1987.

KUROSAWA, Akira. Relato Autobiográfico. São Paulo, Estação Liberdade, 1990.

NOLLETTI, Arthur \& DESSER, David (orgs.). Reframing Japanese Cinema. Indiana University Press, 1988.

OLIVEIRA, José Eduardo Marques de. Cinema Japonês. São Paulo, Massao Ohno Editora,1962.

RICHIE, Donald. The Japanese Movie. Tóquio/Nova York/São Francisco, Kodansha, 1987.

SHINOBU \& GIUGLARIS, Marcel. Le Cinéma Japonais. Paris, Editions du Cerf, 1956. 